\title{
Gender Equality under the Japanese Constitution
}

\author{
By Annette Marfording
}

\section{Introduction}

After the end of the Second World War the Allied Forces in Japan strongly influenced the shape of the Japanese Constitution in 1946. The terms of Japan's surrender contained an obligation for the Japanese government to introduce a democratic form of government and to establish fundamental human rights. A substantial catalogue of individual rights provisions was indeed included in the Constitution and, for the first time, gender equality was constitutionally recognized and protected by two specific articles. ${ }^{1}$ Implementation of the equal rights provisions followed in electoral, educational, employment and family laws.

This paper explores to what extent formal gender equality has been transformed into substantial, that is, result equality. The focus is on education, employment and family law, examined from a historical, legal, political, economic and cultural perspective. The discussion will show that law by itself does little to affect social reality. Instead, the state emerges as the central factor in structuring gender relationships.

\section{Historical Background}

Before addressing the present status of gender equality in Japan, it is appropriate to give a brief account of state policies and legal provisions affecting the position of Japanese women before the coming into force of the Constitution in 1947, in order to place the discussion in a proper perspective.

\section{The Tokugawa Period (1600-1868)}

The Tokugawa period was characterised by the emergence of centralised government and supreme bureaucratic control. ${ }^{2}$ To solidify its position, the Tokugawa shogunate adopted

Articles 14 and 24 of the Constitution, 1946.

2 Michael Young / Constance Jameson, Introduction to Japanese Law, in: CCH International, Japan Business Law Guide, 1988, pp. 1-230. 
Chinese Neo-Confucian ideology, adapted for its purposes to incorporate for instance the ideal of loyalty to one's lord over one's family. ${ }^{3}$ In accordance with Neo-Confucian thoughts, a rigid social structure was introduced, encapsulating the five major human relationships of Confucianism: ruler and subject, father and son, husband and wife, elder and younger brother, friend and friend. ${ }^{4}$ Only in the friend and friend relationship were the participants equal, all the others required respect and obedience on the part of the subordinates to the superiors. ${ }^{5}$ The fundamental basis of society was individuals acting in accordance with their proper social roles. This would lead to harmony which in itself would support the state. ${ }^{6}$ In promoting such a strictly hierarchical society, the state legitimised and supported the subordination of women to men.

\section{The Meiji Period (1868-1912) and the Period up to the End of the Second World War}

The second major period in Japanese legal history is the Meiji era. The Exclusion Edict of 1639 had led to Japan's almost total seclusion from the rest of the world for almost two hundred years. ${ }^{7}$ Under strong foreign pressure, particularly from the United States, the Japanese Shogunate concluded a number of treaties with foreign nations in the late 1850's and early 1860's. These treaties incorporated the opening of Japanese ports to trade and foreign residence, low import duties and extraterritoriality, which allowed foreigners in Japan to use their own consular courts and laws. ${ }^{8}$ The Japanese regarded these privileges for the foreigners as a national shame and as a first step towards colonisation by foreign powers. ${ }^{9}$ The unequal treaties were one reason for the demise of the Shogunate and for the 'restoration' of the Japanese Emperor who had been only a symbolic figurehead under the Tokugawa Shogunate. Treaty revision became the first priority of the new government. ${ }^{10}$ The foreign powers made it clear that this could be achieved only if the same kind of political, legal and economic system as that of the Western nations was adopted. ${ }^{11} \mathrm{~A}$ delegation led by the politician Hirobumi Itô travelled to Europe to study European

3

6

7
Id., at pp. 1-220.

Wilhelm Röhl, Die historische Entwicklung des japanischen Rechts, in: Harald Baum / Tatjana Stiege (Eds.), Japan - Kultur und Recht: Eine Einführung, Veröffentlichungen der DeutschJapanischen Juristenvereinigung, Band 2, Hamburg 1993, p. 39, at p. 42.

Id., at p. 43.

Ibid.

Michael Young / Constance Jameson, note 2 supra, at pp. 1-220.

Ken Mukai/Nobuyoshi Toshitani, The Progress and Problems of Compiling the Civil Code in the Early Meiji Era, translated by Dan Fenno Henderson, Law in Japan 1 (1967), p. 25, at p. 32.

Id., at 31; Wilhelm Röhl, note 4 supra, at p. 45.

Wilhelm Röhl, ibid.

Id., at p. 46; Ken Mukai / Nobuyoshi Toshitani, note 8 supra, at p. 33. 
constitutional monarchies. The delegation concluded that the Prussian monarchical constitution would be an ideal model, since it secured the monarch far reaching influence and was based on nationalist and authoritarian ideas. ${ }^{12}$ The Meiji Constitution was drafted accordingly, promulgated in 1889, put into effect in 1890 and remained in force until 1947 when the new Constitution came into effect. The Constitution provided for a Diet composed of elected representatives, but sovereignty resided in the Emperor. Women were excluded from voting by the electoral laws. ${ }^{13}$ The Constitution included individual rights' protection but 'within the limits of law'. Gender equality was not part of these provisions.

The draft Civil Code of 1888 caused much controversy as a result of draft sections concerning the family, which included stipulations that parties were to marry based on their own free will, that parental consent to a marriage between adults was unnecessary, and which in other ways weakened the family order. ${ }^{14}$ Under the pre-existing family or ie system the family was a patriarchal organisation in which the head of the family (a position which was inherited by the eldest son) had supreme authority, and obedience of the family members to him was the foremost duty. ${ }^{15}$ This $i e$ system was the foundation of society, for it was in the family where people first learned the meticulous respect rules which governed social behaviour. ${ }^{16}$ The importance of the ie system was reinforced by its association with political ideology which visualised Japan as a family state whose head was the divine emperor to whom subjects owed total obedience. ${ }^{17}$

Traditionalists vigorously attacked draft provisions concerning the family such as the ones mentioned above on the ground that 'to recognize independence of the individual members of the Iye [sic] and give them a wide range of rights' was 'absolutely incompatible with and contradictory to the reality of the Iye [sic] we have now' and that the draft 'lacked the idea of our [unique] polity'. ${ }^{18}$ According to Isono, Yatsuka Hozumi, one of the leading opponents, contended that

the Head of the Iye [sic] was the incarnation of the whole line of ancestors and his authority was sacred and inviolable; and that all members of the Iye [sic] owed unconWilhelm Röhl, note 4 supra, at p. 49.

Fujiko Isono, The Evolution of Modem Family Law in Japan, International Journal of Law and the Family 2 (1988), p. 183, at p. 186.

Kurt Steiner, Post-war Changes in the Japanese Civil Code, Washington Law Review 25 (1950), p. 286, at pp. 289-290.

Ruth Benedict, The Chrysanthemum and the Sword, Patterns of Japanese Culture, Houghton Mifflin Company, 1946, at p. 48.

Fujiko Isono, note 14 supra, at p. 184.

Quoted from id., at p. 186. 
ditional obedience to him. Only the eldest son should be the heir to his status, and all decisions concerning any change in the status of one of its members, such as marriage, divorce and adoption had to be taken for the benefit of perpetuating the cult of Iye $\left[\right.$ sic ${ }^{19}$

Many of the antagonists would have been influenced by an awareness that a dissolution of the ie system would involve a devolution of their own power. They would also have realised that because of the link between the $i e$ system and the political ideology of the family state the whole political power structure could be affected. From an economic perspective, too, the $i e$ system was supported as well suited to a predominantly agricultural society in which the handing down of undivided land holdings to the eldest son was an effective means of ensuring that land remained in viable production units. ${ }^{20}$

After long discussions and further drafts the Civil Code finally came into effect in 1898. It was largely based on the draft German Civil Code published in the meantime, but also drew on numerous other European legal systems. ${ }^{21}$ In the areas of family law and succession, however, the ie system was made the basic legal unit of society, ${ }^{22}$ since abolition of Japanese customs in these areas was not essential to achieving the aims of treaty revision and industrial modernisation. While some compromise between the opposing factions was achieved, the family system remained substantially intact ${ }^{23}$ and was further strengthened by moral teaching in the education system. Volume 1 of the Series of Manuals for Education in Family Life published by the Ministry of Education in 1944 states

The lord is the head and the subject is the tail. The father is the head and the child is the tail. Continuing the same logic, the husband is the head and the wife the tail. Therefore, the husband is noble and the wife is humble. For the wife her husband is the Heaven. One cannot escape from Heaven. As one is always under Heaven, the wife is always under the (authority of her) husband wherever she may be. Without her obedience to the husband there is no happiness nor honour for her. ${ }^{24}$

This advocates not only a strong hierarchy within the family without protection or respect for the wife but also the ideology of the family state.

19

20

21

22

23

24

Id., at p. 187.

Kurt Steiner, note 15 supra, at p. 289.

Wilhelm Röhl, note 4 supra, at p. 51; Zentaro Kitagawa, Theory Reception - One Aspect of the Development of Japanese Civil Law Science, translated by Ronald Lee, Law in Japan 4 (1970), p. 1 , at p. 3.

Kurte Steiner, note 15 supra, at p. 288.

Fujiko Isono, note 14 supra, at p. 193.

Quoted idl, at p. 194. 
A few exemplary provisions of the Civil Code at that time may illustrate the legal significance of the $i e$ system. The family head could expel members from the family unit if they married without his consent. ${ }^{25}$ Grounds for divorce included adultery on the part of the wife only and her grossly insulting her husband's lineal ascendants. ${ }^{26}$ During the marriage a wife needed her husband's consent for legal acts ${ }^{27}$ and her property was managed by her husband. $^{28}$

\section{As Steiner succinctly states}

democracy and the family system are incompatible. Democracy is based on individualism, an ideology which is the very antithesis of the family system. While one aims at developing individuality, the other would sacrifice it for the good of the unit; while one desires equality, the other believes that a rigid hierarchy is essential to order, ... one is based on the idea of right and the other on the notion of duty. ${ }^{29}$

To develop its economic system in resistance to the Western imperialist countries, the Japanese government worked towards rapid industrialisation of the country. Strong government support went towards heavy industry to develop the military force but also to the textile industry, particularly cotton spinning, silk reeling and cotton and silk weaving, to compete against imported foreign textile products and to increase Japan's export potential. $^{30}$

According to Tsurumi, textile plants employed about three quarters of factory workers in Japan in 1882. ${ }^{31}$ A large majority of these were women and young girls, often recruited from poor peasant families in return for cash paid to their fathers. ${ }^{32}$ Tsurumi observes that these cash advances as well as the recruiters' expenses for accommodation, travelling, meals etc. were deducted from the textile workers' wages. ${ }^{33}$ While male workers in the textile industry were usually paid fixed wages, female workers' wages were based on individual production levels. ${ }^{34}$ Women were penalised for poor performance, which could result not

\section{Old articles 14 and 16.}

28

Old article 801.

Kurt Steiner, note 15 supra, at pp. 289-290.

E. Patricia Tsurumi, Female Textile Workers and the Failure of Early Trade Unionism in Japan, History Workshop 18 (1984), p. 3, at pp. 4-5. Id., at p. 5.

Ibid.

Ibid. Id., at p. 6. 
only from factors such as a lack of skill and ill health but also from machinery breakdown and low quality materials. ${ }^{35}$ Female workers' wages were thus twenty to twenty-five per cent lower than those of men. ${ }^{36}$ Working conditions for women included working hours of up to 18 hours a day, extremely crammed accommodation in locked dormitories adjacent to the factories, checking of private mail by dormitory supervisors, hazardous machinery and sexual abuse. ${ }^{37}$ Factory management lectured their workers on the importance of obeying the employer and putting all one's energies into high production levels in loyalty to the nation. ${ }^{38}$ Japan's industrial revolution thus depended significantly on the exploitation and subordination of women and young girls.

\section{Legal Developments Towards Gender Equality}

The foremost concern of the Allied Forces in Japan after the end of World War II was for Japan to have a democratic form of government. Thus, section 10 of the Potsdam Declaration of 26 July 1945, which contains the terms of Japan's surrender to the Allied Powers, states:

The Japanese Government shall remove all obstacles to the revival and strengthening of democratic tendencies among the Japanese people. Freedom of speech, of religion and of thought, as well as respect for the fundamental human rights shall be established.

Ward $^{39}$ gives an interesting account of how the Supreme Commander for the Allied Powers (SCAP) in effect drew up the Japanese Constitution of 1946 as a result of General MacArthur's dissatisfaction with Japanese drafts, which constituted only minor revisions of the Meiji Constitution. According to Ward the Japanese government was pressured into proclaiming a constitution similar to the American draft ${ }^{40}$ by statements made by General Whitney, Chief of MacArthur's Government Section, that if this was not done, the person of the emperor could not be guaranteed. ${ }^{41}$ In addition General Whitney threatened to take constitutional reform to the Japanese people for discussion. ${ }^{42}$ Considering the difficult

Ibid.

Ibid.

Id., at pp. 6-9.

38 Id., at p. 12

Robert Ward, The Origins of the Present Japanese Constitution, American Political Science Review 50 (1956), p. 980.

See Kyoko Inoue, MacArthur's Japanese Constitution, A Linguistic and Cultural Study of its Making, University of Chicago Press 1991, at pp. 303-314.

Robert Ward, note 39 supra, at p. 997.

42 Id., at p. 996. 
economic and social circumstances after defeat and the uprise of left-wing political activities, the Japanese people may well have advocated an even more progressive constitution. The difficulties of such an imposed constitution becoming living law in Japan in the face of governmental opposition to many of its aspects including popular sovereignty are thus immediately apparent.

The new Constitution includes a far more comprehensive catalogue of individual rights provisions than the Meiji Constitution did. The two provisions relating to gender equality are articles 14 and 24. Article 14(1) provides

All of the people are equal under the law and there shall be no discrimination in political, economic or social relations because of race, creed, sex, social status or family origin.

According to article 24

Marriage shall be based only on the mutual consent of both sexes and it shall be maintained through mutual co-operation with the equal rights of husband and wife as a basis.

(2) With regard to choice of spouse, property rights, inheritance, choice of domicile, divorce and other matters pertaining to marriage and the family, laws shall be enacted from the standpoint of individual dignity and the essential equality of the sexes.

Implementation of the Constitution required extensive legislative work, both in amendments to existing legislation and in new enactments. This was especially so in the areas of family law and succession, for as noted above, the family system was fundamentally incompatible with individual rights in general and gender equality in particular. The very notion of equality, implying the existence of horizontal relationships, was at odds with the vertical structure of Japanese society. Since the family system was so intrinsic to Japanese society, implementation of the new constitutional principles was particularly difficult in these areas.

According to Steiner, the new family law provisions of the Civil Code constitute a compromise between Japanese conservatives who rejected abolition of the family system and Japanese liberals who opposed the family system as outmoded. ${ }^{43}$ While the previous requirements of the family head's consent to marriage of the family members as well as of parental consent, except when the child is a minor, were abolished, ${ }^{44}$ article 730 requires the mutual co-operation of lineal relatives by blood and relatives living together. This provision is reminiscent of the family system's notion of filial piety. The family law 
provisions rely extensively on the mutual agreement between husband and wife on matters such as marital surname, ${ }^{45}$ child custody ${ }^{46}$ and division of property after divorce, ${ }^{47}$ and the partition of the estate ${ }^{48}$. Divorce can also be effected by agreement. ${ }^{49}$ Formal inequality between men and women remains only in relation to age requirements at marriage (sixteen for women and eighteen for men) ${ }^{50}$ and in relation to a woman's remarriage after dissolution of her previous marriage, which is not allowed until six months after dissolution or until delivery of a child from that marriage. ${ }^{51}$ There have been few amendments to the family law provisions since the amendments designed to implement the new Constitution. A 1976 amendment to the Civil Code now allows persons who have changed their name at marriage to continue using the marital surname after divorce. ${ }^{52}$ Formally, gender equality has thus been substantially implemented in family law.

In the employment area the Labour Standards Law of 1947 introduced equal pay for equal work. ${ }^{53}$ In addition, an Equal Employment Opportunity Act was passed in 1985, the effectiveness of which will be considered below. In relation to education, article 26 of the Constitution provides that

All people shall have the right to receive an equal education correspondent to their ability, as provided by law.

(2) All people shall be obligated to have all boys and girls under their protection receive ordinary education as provided for by law. Such compulsory education shall be free.

In 1947 the Fundamental Law of Education was passed, providing for equal opportunity in education $^{54}$. Article 44 of the Constitution prohibits sexual discrimination in the right to vote and be elected, which has been implemented by the electoral laws.

Having regard only to the actual laws, it can be said that the Constitution has been effectively implemented in terms of gender equality. But law does not necessarily translate into reality. The effectiveness of laws is affected by political and economic factors and

\begin{tabular}{l|l}
45 & Article 750. \\
46 & Article 766. \\
47 & Article 768. \\
48 & Article 907. \\
49 & Article 763. \\
50 & Article 731. \\
51 & Article 733. \\
52 & Article 767. \\
53 & Article 4. \\
54 & Article 3. \\
&
\end{tabular}


dependent upon governmental support as well as the attitudes and response of the population. $^{55}$

\section{Substantial Gender Equality?}

The question whether formal gender equality has been transformed into substantial, that is, result equality, must be examined by considering the political, economic and cultural context in Japan. History, which shows that gender equality is a fairly recent concept in Japan, should also be kept in mind.

\section{Education}

Gender equality in schools and universities is crucial for achieving gender equality in employment. ${ }^{56}$ In most societies education levels and employment opportunities are closely related, but in Japan this is even more so than in other societies. Japanese companies offer employment on the basis of university name rather than on the basis of what the applicant has studied or what grades he or she has achieved at university. ${ }^{57}$ Surveys show that by far the majority of top company presidents are former graduates of the two highest ranking public universities, Tokyo and Kyoto, and of the two highest ranking private universities, Keio and Waseda. ${ }^{58}$ In the bureaucracy, former Tokyo University graduates dominate even more clearly. 59

The key for access to the top ranking universities lies in the university entrance examinations. Since employment opportunities are so vitally dependent upon the rank of the university attended, the educational process as a whole becomes highly competitive and geared towards the university entrance examinations. Rohlen describes its intensity as follows:

Lawrence Friedman, Legal Culture and Social Development, Law and Society Review 4 (1969), p. 29, at p. 34.

Deborah L. Rhode, Feminism and the State, Harvard Law Review 107 (1994), p. 1181, at p. 1198.

57 Ronald P. Dore, The Future of Japan's Meritocracy, in: Gianna Fodella (Ed.), Social Structures and Economic Dynamics in Japan up to 1980, Series on East Asian Economy and Society, Volume 1, 1975, p. 169, at pp. 174 and 177; Thomas P. Rohlen, Education in Japanese Society, in: Daniel Okimoto / Thomas P. Rohlen (Eds.), Inside the Japanese System: Readings on Contemporary Society and Political Economy, Stanford University Press, 1988, p. 25, at p. 28. William K. Cummings, Education and Equality in Japan, Princeton University Press, 1980, at p. 238. 
Nothing better illustrates the pressure to begin preparations early than the popularity of cram schools, or juku, which today enrol [sic] one in three middle school students and one in four upper elementary students across the nation ... Juku are privately run afterschool academies designed to supplement public education ... The typical pattern for juku is a couple of hours a few days a week, but more aggressive and fast-paced cram schools hold classes more regularly, even on weekends and during vacations. Juku management is now a booming growth industry, complete with franchising and educational conglomerates. Private entrepreneurship and parental anxiety have combined with entrance exam pressures to create an unprecedented phenomenon, which some critics feel threatens to make Japanese childhood a tightly scheduled existence in which children are shuttled from home to school to juku to home, with no time for friends or play. ${ }^{60}$

Do women have equal opportunity in this process? The examination system appears to suggest that success is purely based on merit. Indeed, recent figures produced by the Ministry of Education show that the percentage of female students advancing to university now exceeds that of male students. ${ }^{61}$ Nevertheless, these figures deserve closer scrutiny. In 1980 , only seven and eight per cent respectively of those entering the two highest ranking public universities, Tokyo and Kyoto, were women. ${ }^{62}$ The percentage of women at law faculties of high ranking private universities today is only approximately twenty per cent. ${ }^{63}$ Whereas male students generally choose four-year university courses, ${ }^{64}$ women mostly enrol in two-year courses at junior colleges ${ }^{65}$ (formally part of the term "university"), particularly in areas of study such as home economics, education, arts and nursing. ${ }^{66}$

The reasons for the low percentage of women entering universities lie partially in parental attitudes towards their daughters' education. ${ }^{67}$ A 1984 parental opinion poll showed that 51.1 per cent of parents expected their sons to attain university level whereas only 18.9 per

Reported in Asahi Shimbun, Japan Almanac 1993, Asahi Shimbun Publishing Company, 1992, at p. 224.

62

Thomas $P$. Rohlen, note 57 supra, at p. 28.

Thomas P. Rohlen, note 59 supra, at p. 85.

Informal communication to the author by law professors teaching at Waseda and Chuo Universities.

Women constituted 27.4 per cent of total enrolment in 1990: Nihon Fujin Dantai Rengô kai hen, Fujin Hakusho 1992 [Federation of Japan Women's Associations (ed.), Women's White Paper, 1992], at p. 275 , table 65.

Thomas $P$. Rohlen, note 59 supra, at p. 85.

Kevin A. Collins, Education in Japan: Statistical Comparisons with Australia, Australian Government Publishing Service, 1989, at pp. 19 and 21.

Thomas $P$. Rohlen, note 57 supra, at p. 31. 
cent of parents expected this for their daughters. ${ }^{68}$ Even the Director of Women and Youth Bureau of the Ministry of Labour, Ryoko Akamatsu, has reportedly stated that 'graduation from a top school can hurt a woman's marriage prospects'. ${ }^{69}$ These attitudes may well be reflected in a reluctance of parents to pay for private school education and/or cram schools for their daughters, which is likely to disadvantage them in entrance examinations.

Instead of attempting to overcome such cultural pressures on girls, education policies actively promote such cultural attitudes. School text books stereotype women as housewives and mothers, history books omit any reference to women, and women writers are marginalised in literature courses. ${ }^{70}$ Home economics, described by Rohlen as 'an introduction to the family and to household management', ${ }^{71}$ is taught to females only. ${ }^{72}$ It is significant that a 1983 document of the ruling Liberal Democratic Party (LDP) demanded an even greater emphasis on home economics courses at school. ${ }^{73}$

In addition to these cultural influences, women may realise that even graduation from a top ranking university will not necessarily secure them employment in large corporations. Omori suggests that employers prefer men to have a higher education whereas they prefer women not to. ${ }^{74}$ The Asahi Evening News reported in July 1993 that major Japanese companies planned to hire 68,930 new male graduates in 1994 but only 12,182 new female graduates. ${ }^{75}$ One week earlier the Japanese Labour Ministry had reportedly taken the unprecedented step of sending letters to economic organisations, appealing to them to employ more women, after an increasing number of companies turned down applications by female university and junior college students. ${ }^{76}$

Cited by Masako Kamiya, Women in Japan, U.B.C. Law Review 20 (1986), p. 447, at p. 465 , table 3. Quoted in Jane Condon, A Half Step Behind - Japanese Women Today, Charles E. Tuttle Company, 1992, at p. 145.

Sandra Buckley / Vera Mackie, Women in the new Japanese State, in: Gavan McCormack / Yoshio Sugimoto (eds.), Democracy in Contemporary Japan, Hale \& Iremonger, 1986, p. 173, at p. 182.

Sandra Buckley and Vera Mackie point out that this occurs in direct contravention of United Nations guidelines, note 70 supra, at p. 182. Id., at p. 174.

74 Maki Omori, Gender and the Labor Market, Joumal of Japanese Studies 19 (1993), p. 79, pp. 8889. 
As explained below, top positions in large corporations require frequent overtime work and socialising after hours with colleagues, ${ }^{77}$ and a long period of service uninterrupted by time devoted to child bearing and rearing, all of which is extremely difficult if not impossible for women with children. Although childcare centres exist, there are not enough, they are expensive and their opening hours are not adequate for full-time career women. ${ }^{78}$ Under these circumstances it is not surprising that few women choose to pursue the formidable process of preparing for the entrance examinations to top ranking universities.

\section{Employment}

The labour force participation rate of Japanese women has rapidly increased since World War II, reaching 50.1 per cent in $1990 .^{79}$ The proportion of married women in employment has increased from 38.6 per cent in 1965 to 58.4 per cent in $1990{ }^{80}$ This has led some to claim that the increase of opportunities outside the home for married women has given them 'great freedom to decide how, where, and under what terms they will work'. ${ }^{81}$ It is my contention that this freedom of choice is at best limited and that Japanese women continue to be discriminated against in employment.

The unequal position of women is supported by both the internal labour market in Japan and government policies. It has often been said that the Japanese internal labour market is characterised by lifetime employment, a seniority based wage system, and enterprise unionism. $^{82}$ Lifetime employment means that workers are employed after graduation, receive in-house-training, and remain with the same company until retirement at about 55 years of age. A seniority based wage system involves wage increases depending more on age and length of service than job performance. Enterprise unionism involves union organi-

Ross Mouer / Yoshio Sugimoto, Images of Japanese Society. A Study in the Social Construction of Reality, Kegan Paul International, 1986, at pp. 253-255; Peter Tasker, Inside Japan: Wealth, Work and Power in the New Japanese Empire, Penguin Books, 1987, at pp. 102-111; Michiko Takahashi, Working Mothers and Families, Review of Japanese Culture (1989), p. 21, at p. 23.

78

79

Alice C.L. Lam, Women and Japanese Management, Discrimination and Reform, Routledge, 1992, at p. 10

80

81

Sumiko Iwao, The Japanese Women: Traditional Image and Changing Reality, The Free Press, 1993, at p. 6.

82

Maki Omori, note 74 supra, at p. 91; Alice C.L. Lam, note 79 supra, at p. 57. It should be noted though that the Ministry of International Trade and Industry has suggested in 1994 that to enhance labour mobility some changes to the lif etime employment system must be made; see John Lyons, Japan foreshadows new approval to jobs, The Australian, 16 March 1994. Some dismissals from lifetime employment have been reported in the press recently. 
sation within an individual company rather than across an industry. ${ }^{83}$ Employees covered by this system are generally those in large firms, and it encompasses no more than one third of the Japanese labour force. ${ }^{84}$ Since companies cannot easily dismiss lifetime employees, the flexibility required for business fluctuations is secured by long overtime hours, job transfers, employment of non-regular workers (including part-time and temporary workers) and by encouraging female employees to retire at marriage or childbirth. ${ }^{85}$ While the courts have held that the practice of forcing female employees to retire at marriage or childbirth is illegal $^{86}$ and the Equal Employment Opportunity Act 1985 prohibits retirement agreements and dismissal on these grounds, ${ }^{87}$ Lam claims that an informal system of encouraging them to do so persists. ${ }^{88}$

I have already referred to the difficulty experienced by women in gaining positions in large corporations and the problems posed by overtime work and transfers for women with children. It is not surprising then that the rise in the labour participation rate of women is due largely to the increase in the number of part-time workers. ${ }^{89}$ There has been little increase in the number of female full-time workers. ${ }^{90}$ The term 'part-timer', however, is often used by employers simply to indicate employment status, but does not necessarily lead to reduced working hours. ${ }^{91}$ In addition, a large proportion of temporary and casual workers are women. ${ }^{92}$ Part-timers, temporary and casual workers are excluded from longterm job security, high salaries, paid holidays, pension benefits granted to regular workers, and from enterprise union membership, which is restricted to regular, full-time workers. ${ }^{93}$

Article 4 of the Labour Standards Law prescribes equal pay for equal work, but a contextual analysis of the Act suggests that it applies only to full-time workers. In 1989, full-time

83

84

85

86

87

88

89

90

91

92

93

Alice C.L. Lam, ibid.

Nanshi F. Matsuura, Sexual Bias in the Nenko System of Employment, Journal of Industrial Relations 23 (1981), p. 310, at p. 313; Peter Tasker, note 77 supra, at p. 109.

Maki Omori, note 74 supra, at p. 91; Alice C.L. Lam, note 79 supra, at pp. 56 and 58.

Sumitomo Cement Company, 17 Rôshû 1407, Tokyo District Court, 20 December 1966; Mitsui Shipbuilding Company, 11 Rôshû 1163, Osaka District Court, 10 December 1971; discussed in Catherine W. Brown, Japanese Approaches to Equal Rights for Women: The Legal Framework, in: John O. Haley (ed.), Law and Society in Contemporary Japan, Kendall/Hunt, 1988, p. 197.

Article 11.

Alice C.L. Lam, note 79 supra, at p. 58.

Id., at p. 55; Michiko Takahashi, note 77 supra, at p. 22.

Ibid.

Alice C.L. Lam, note 79 supra, at p. 56.

Ibid.

Ibid; Tomoko Nakamatsu, Housewives and Part-Time Work in the 1970s and 1980s: Political and Social Implications, Japanese Studies Bulletin 14 (1994), p. 87, at p. 95. 
female employees earned on average merely 57 per cent of the income of full-time workers. ${ }^{94}$ Employers evade their obligation to pay women equal pay for equal work by either describing identical work content differently, or by attaching alternative labels to the same positions. ${ }^{95}$ This reflects Rhode's statement in the American context that 'work performed by women is undervalued because it is performed by women'. ${ }^{96}$

In addition, the seniority based wage system has a discriminatory impact on the many women who interrupt their careers to raise children. ${ }^{97}$ Statistics dealing with the distribution of women in the labour force by age group reflect an M-shaped curve. In 1990 the two peaks occurred at ages 20-24 (75.1 per cent) and at 45-49 (71.7 per cent), with a sharp drop ( 51.7 per cent) at ages $30-34 .^{98}$ There are many reasons why women withdraw from the workforce to raise their children. Employers exert pressures on women to resign at marriage or childbirth, ${ }^{99}$ childcare facilities are inadequate in number and opening times, ${ }^{100}$ and husbands have practical difficulties in sharing housework and childcare duties because of their very long working hours. ${ }^{101}$ In addition, the 'good wife and wise mother' ideal of the old family system and the ideology of sexual division of labour are still prevalent in Japanese society. ${ }^{102}$ According to a 1983 opinion poll, 55 per cent of women thought women should not work while childbearing. ${ }^{103}$ In a 1987 poll 36.6 per cent of women (1990: 25.1 per cent) and 51.6 per cent of men (1990): 34.7 per cent) agreed with the idea that the man is the breadwinner and the woman performs the domestic chores. ${ }^{104}$ Indeed, 85.8 per cent of Japanese men, whether married or unmarried, have never contributed in any way to household tasks according to a recent government survey. ${ }^{105}$ The fact that such large numbers of women subscribe to these ideologies is probably partially due to the education policies discussed above.

94

95

96

97

98

99

100

101

102

103

104

4 Nihon Fujin Dantai Rengô kai hen, Fujin Hakusho 1991 [Federation of Japan Women's Associations (Ed.), Women's White Paper, 1991], at p. 291, table 72.

105

Reported by Olivier Fabre, Study blames lazy Japanese men, Sydney Morning Herald 19, November 1994. 
Following Japan becoming a signatory state to the United Nations Convention to Eliminate All Forms of Discrimination Against Women (CEDAW) in 1980, the Japanese government was forced to act and change labour laws and practices. The result was the Equal Employment Opportunity Act (EEOA) 1985, which came into effect in 1986. Article 2 of the Act throws light on the fundamental beliefs of the law makers about women's role in society. It reads:

In view of the fact that women workers contribute to the development of the economy and society and at the same time have a significant role to play as a member of the family in nursing children - who will be the mainstay of the future - the basic objectives of the improvement of the welfare of women workers as outlined in this Act are to enable them to obtain job satisfaction by making effective use of their abilities, with due respect for their maternity but without discriminatory treatment on the basis of sex, and to achieve harmony between their working life and family life (emphasis added).

Women are thus relegated to their 'proper' role as mothers and home-makers, whereas men are not expected to take responsibility for child-rearing or to play a role in family life. Women are supposed to work outside the home only if this does not negatively affect their family.

The Act prohibits sex discrimination with respect to vocational training, ${ }^{106}$ fringe benefits, ${ }^{107}$ and retirement and dismissal. ${ }^{108}$ With regard to recruitment, hiring, job assignment and promotion the law provides that employers shall endeavour to treat women workers equally with men workers. ${ }^{109}$ The weakness of these provisions is immediately apparent, especially since the law does not prescribe any sanction for any failure to endeavour to fulfil these purely moral obligations.

For the settlement of disputes between employers and employees the main emphasis is on voluntary settlement within the company ${ }^{110}$; if that is unsuccessful, the only remedy is mediation before the Equal Opportunity Mediation Commission subject to the consent of both parties, ${ }^{111}$ which in practice gives the employer a veto power. Even if it comes to mediation, the Commission can only make a proposal for mediation and recommend its acceptance to the parties concerned, ${ }^{112}$ but cannot force the parties to accept it, nor take the

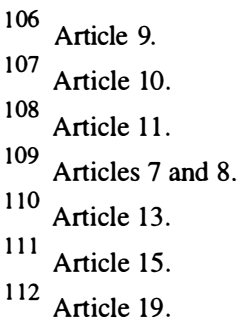


refusing party to court. According to a report published by the Ministry of Labour in 1988 only 5781 cases were so mediated in the two years since the coming into force of the EEOA and only eight per cent of these were in relation to the 'endeavour' articles 7 and $8 .{ }^{113}$ Even in America, where society is far more litigious than in Japan, victims of discrimination do not often identify themselves as such. Rhode suggests 'they prefer to avoid the hostility, as well as the diminished sense of efficacy and self-esteem, that acknowledging one's victimisation typically entails. ${ }^{114}$ How much more would this apply in Japan where women have been taught for generations to be subservient to men and to not question authority. The weakness of the EEOL is due largely to strong resistance and lobbying by employer groups during the legislative drafting process. ${ }^{115}$

Article 12 empowers the Labour Ministry to issue guidelines to employers in respect of measures which employers shall endeavour to take in regard to Articles 7 and 8, but the Act does not prescribe any standards for such measures or guidelines. While administrative guidance is generally a very strong enforcement mechanism in Japan, ${ }^{116}$ the Ministry has so far not taken a very proactive approach in this area. As Lam explains, the guidelines issued in 1986 permit employers 'to classify jobs into different streams such as 'managerial' and 'clerical', provided that employers do not restrict women exclusively to the clerical stream but offer them opportunities to be assigned to managerial jobs.' ${ }^{117}$

While Lam reports that the law has led to some positive changes in recruitment of women, ${ }^{118}$ the 1993 appeal by the Japanese Labour Ministry to companies to employ more women $^{119}$ seems to suggest otherwise. In addition, the 1986 guidelines by the Ministry which allow streaming in job classification, seem to be responsible for the new recruitment practices in many large firms, in which new employees are classified into two streams: the managerial (sôgôshoku) and the general (ippanshoku). ${ }^{120}$ The managerial track requires a commitment to mobility in job rotation and transfers and offers unlimited promotion potential, whereas the general track limits job rotation and transfers, but also promotion. ${ }^{121}$

113 Reported by Seigo Hirowatari, Die Förderung der Gleichberechtigung von Mann und Frau in 114 Japan, Recht in Japan 8 (1991), p. 39, at p. 59.

Deborah L. Rhode, note 56 supra, at p. 1189

115 Alice C.L. Lam, note 79 supra, at pp. 95-99; Seigo Hirowatari, note 113 supra, at p. 54.

116 Michael K. Young, Judicial Review of Adminstrative Guidance: Govemmentally Encouraged Consensual Dispute Resolution in Japan, Columbia Law Review 84 (1984), p. 923; Elliott J. Hahn, Japanese Business Law and the Legai System, Quorum Books, 1984, pp. 117-121.

117 Alice C.L. Lam, note 79 supra, at pp. 107-108.

118 Id., at p. 125.

119 See text accompanying note 76 supra.

120 Alice C.L. Lam, note 79 supra, at p. 128; Tomoko Nakamatsu, note 93 supra, at pp. 96-97.

121 Alice C.L. Lam, id., at pp. 128-129. 
Clearly this career division has a disparate impact on women who will find it much more difficult to combine the expected mobility with their family lives than men. While the managerial track is formally open to men and women, 99 per cent of men are assigned to it automatically, whereas women are offered the choice and submitted to tough scrutiny in selection interviews about their commitment to mobility and their family lives. ${ }^{122}$ According to a 1991 survey, only 3.7 per cent of women were classified into the managerial track. $^{123}$

In job assignment and promotion the hortatory provisions of the Equal Employment Opportunity Act have been notably unsuccessful, largely as a result of the new career tracking system. ${ }^{124}$

When the EEOL was introduced, complementary amendments to the Labour Standards Law were enacted, removing protective restrictions on overtime, late-night and holiday work for women and abolishing menstrual leave. ${ }^{125}$ The amendments came in response to management pressures during the EEOL drafting process. ${ }^{126}$ The changes have had a negative impact on part-time workers who often don't receive increased pay for overtime and night shift work ${ }^{127}$ and who benefit neither from the Labour Standards Law nor from the EEOL, since both Acts are interpreted as only applying to regular full-time workers. ${ }^{128}$

In summary, it can be strongly argued that the introduction of the Equal Employment Opportunity Act has aggravated and institutionalised the subordination of women in employment rather than leading to equal employment opportunity. ${ }^{129}$

In 1991 the Japanese Diet passed a Child Care Leave Act, which came into effect in 1992. The Act gives parents of either sex who are in permanent employment a legal right to claim one year's parental leave without pay for children aged less than one year. While this is a step in the right direction, it is unlikely that many fathers will take advantage of this right in

122

Id., at p. 131; Tomoko Nakamatsu, note 93 supra, at p. 97; Seigo Hirowatari, note 113 supra, at p. 60 .

123 Women's White Paper, 1991, note 104 supra, at p. 21.

124 Alice C.L. Lam, note 79 supra, at pp. 133-135.

125 Id., at p. 98; Seigo Hirowatari, note 113 supra, at pp. 56-57.

126

Alice C.L. Lam, ibid.

127 Tomoko Nakamatsu, note 93 supra, at p. 98.

128 See text following note 93 supra; Maki Omori, note 74 supra, at p. 92.

129 So argued by Tomoko Nakamatsu, note 93 supra, at p. 96. 
the context of women's significantly lower average earnings ${ }^{130}$ and the low number of men taking responsibility for home duties and child care. ${ }^{131}$

The Japanese internal labour market structurally discriminates against women in terms of access to regular full-time employment and its benefits. The resultant cheap and flexible use of female labour produces increased company profits and advances the economic progress of the nation. As in the Meiji period, Japan's economic success depends significantly on women.

To achieve substantial gender equality in employment, major changes in the structure of the Japanese labour market are necessary. This would include the overhaul of lifetime employment and seniority based wages, the reduction of working hours, the introduction of strong affirmative action strategies coupled with effective penalties for non-compliance, and the protection of wages and benefits for part-time and temporary workers. It is extremely unlikely, however, that the Japanese government would be willing and able in the face of strong employer resistance to achieve substantial progress for gender equality in this area.

Government policies in taxation and welfare indeed help to undermine gender equality in Japan. The tax system makes it financially attractive for married women to limit their income. If a married woman earns less than one million yen a year, not only is her income not taxed, but in addition her husband is entitled to a dependent spouse tax rebate. ${ }^{132}$ Taxation policies thus strengthen the sexual division of labour in Japanese society.

The inducement for women to work only part-time incidentally frees them to look after the elderly. Faced with a rapidly ageing society the government is attempting to encourage individual families to look after elderly parents, while simultaneously reducing social welfare expenditure. ${ }^{133}$ It is obvious that this welfare burden will have to be carried by women, often daughters-in-law. Here the practical significance of article 730 of the Civil Code becomes apparent, which requires the mutual co-operation of lineal blood relatives and relatives living together.

When seen in combination with the education policies described above and the non-assertiveness during the EEOL drafting process, the government's stance clearly bears part of the responsibility for gender inequality in Japan.

\footnotetext{
130 Text accompanying note 94 supra.

131 Text accompanying note 105 supra.

132 Tomoko Nakamatsu, note 93 supra, at p. 92 . Moreover, 89.3 per cent of companies provide an 133 additional dependent allowance.

Id., at p. 93.
} 


\section{Family Law}

I have previously referred to the changes in family law following enactment of the 1946 Constitution, which formally put women on an equal footing with men.

Section 750 of the Civil Code provides that husband and wife need to agree on a single marital surname. In view of the cultural attitudes conveyed by the education policies, it is not surprising, however, that in more than 96 per cent of marriages the husband's surname is adopted. ${ }^{134}$ This is discriminatory for women since giving up one's surname can often involve losing one's sense of identity and independence, apart from the inconvenience caused by any name change. These problems are universal but perhaps even more stringent in Japan where female subordination was a legally sanctioned fact only fifty years ago. In 1993 the case of Reiko Sekiguchi, Professor of Sociology at the University of Library and Information Science at Tsukuba, came to worldwide attention. ${ }^{135}$ Upon her marriage she had been registered under her husband's name in the family register, but had continued to use her maiden name for social and professional reasons. The Tokyo District Court ruled that she could not use her maiden name at work for official purposes such as receipt of salary, research grants or travel allowances. The presiding judge, Judge Atsuhi Fukui, is reported to have said that

For a married couple to use the same name helps to strengthen the sense of oneness between them, clearly signifies that they are married and is ... not against the Constitution. $^{136}$

In contrast, the obligation for a couple to agree on a single marital surname has been declared as violating the constitutional equality provisions and therefore unconstitutional by the German Federal Constitutional Court in 1991. ${ }^{137}$

As noted earlier, the family law provisions have a strong emphasis on the mutual agreement of the spouses in other matters, too, such as child custody and division of property after divorce. $^{138}$ If even before marriage more than 96 per cent of agreements favour the husband, what hope does this give to women for agreements in the event of divorce? Even

134 Yukiko Matsushima, Japan: The Way Forward in Family Law, Journal of Family Law 30 (199192), p. 349, at p. 353.

135 Ben Hills, Professor loses court battle for right to use maiden name, Sydney Morning Herald, 24

136 November 1993.

Ibid.

37 Nobuyoshi Toshitani, The Reform of Japanese Family Law and Changes in the Family System (translated by Amy Searight), U.S. - Japan Women's Journal No. 6 (1994) (English Supplement), p. 66 , at p. 79 .

Articles 766 and 768 Civil Code. 
if some women in violation of social norms are prepared to fight for their rights vigorously, the much stronger bargaining position of the man is indisputable.

The same concerns are relevant to divorce effected by agreement. ${ }^{139}$ The agreement does not have to encompass terms on child support or property distribution; designation of the custodial parent is all that is necessary. To secure an agreement on financial matters after divorce will be even more difficult than before because the woman's bargaining power will have declined further. There is evidence, too, that some divorces by 'agreement' are effected fraudulently since appearance in person is unnecessary. ${ }^{140}$ Divorce papers sent by mail will be accepted if both parties and two witnesses have affixed their seals to them and seals are readily available in Japan. ${ }^{141}$ It is instructive to consider divorce by agreement in its historical context, particularly since this apparently modern facility was already part of the Meiji Civil Code. As Isono explains,

according to the value system of the Iye [sic] the yome [wife] who did not please the parents of her husband had to be removed from the Iye [sic] circle. Failure to produce a male heir was one of the main and accepted reasons; but the most common justification was that she did not fit into the 'culture' of the Iye [sic], especially from the mother-inlaw's point of view. ...[A] yome who was found undesirable had to be expelled in order to maintain the solidarity of the Iye [sic] group. Nevertheless, it was not possible to write into a modern civil code [the Meiji Civil Code] a provision allowing the daughter-in-law to be divorced arbitrarily. Hence this 'mutual consent' for divorce, so that the yome could easily be forced to consent. ${ }^{142}$

The incidence of fraudulent submission of divorce papers can be explained partly as related to this historical context and partly as due to the difficulties of achieving a divorce by means other than an agreement. Article 770 of the Civil Code provides:

Husband or wife can bring an action for divorce only in the following cases:

1. If his or her spouse has committed an act of unchastity;

2. If he or she has been deserted maliciously by his or her spouse;

3. If it is unknown for three years or more whether his or her spouse is alive or dead;

4. If his or her spouse is attached with severe mental disease and recovery therefrom is hopeless;

5. If there exists any other grave reason for which it is difficult for him or her to continue the marriage.

139

Article 763 Civil Code.

140 Taimie L. Bryant, Marital Dissolution in Japan: Legal Obstacles and their Impact, Law in Japan 17 (1984), p. 73, at p. 95.

141

Ibid.

142

Fujiko Isono, note 14 supra, at p. 191. 
Even in cases where any or all of the grounds mentioned in items 1 to 4 inclusive of the preceding paragraph exist, the Court may dismiss the action for divorce, if it deems the continuance of the marriage proper in view of all the circumstances.

The Japanese courts have been very reluctant to grant a divorce to a spouse responsible for marital breakdown against the will of his or her spouse. ${ }^{143}$ In 1987 the Japanese Supreme Court established a new principle under which that party will be allowed to obtain a divorce if (1) there has been a long period of separation, (2) no underaged children are involved, and (3) no undue mental, social or financial hardship will fall on the wife following divorce. ${ }^{144}$ In this case the parties had lived separately for thirty-six years. ${ }^{145}$ Since then the courts have shortened the required period of separation down to ten-plus years in $1990 .{ }^{146}$ The reluctance of the Japanese courts to grant divorces is said to be due to concerns about the disproportionate financial impact a divorce might have on women, since most Japanese married women devote themselves to work in the home and earn at best a limited income. ${ }^{147}$ This argument does not stand up to closer scrutiny, however, as it is unlikely that husbands would maintain their wives during the separation period. It would seem more plausible to change the law, which presently does not provide for spousal maintenance after divorce, nor does it provide any clear guidelines on property division after divorce. The real difficulty for women is that the law relies on the parties reaching an agreement on property division and failing that, leaves it up to the discretion of the Family Court as to whether any distribution of property is to be made, and if so, for what sum. This is coupled with a property system during marriage under which each party owns separately what they individually acquire during the marriage ${ }^{148}$, thus taking into account neither the contributions of the homemaker nor the income earning potential sacrificed by the woman to look after her family. Since women will experience a substantial income fall after divorce as a result of their sacrifices, strict guidelines on property division after divorce should be introduced, which give women the right to receive a share of the family assets proportional to their contributions as homemaker and which take into proper account her sacrificed income earning potential.

A government committee is currently working on family law reform in relation to the minimum age for marriage (which is currently unequal for men and women under article 731), a woman's remarriage after divorce (article 733), marital surname, division of property after divorce and the question of no fault divorce. Nobuyoshi Toshitani, a distin-

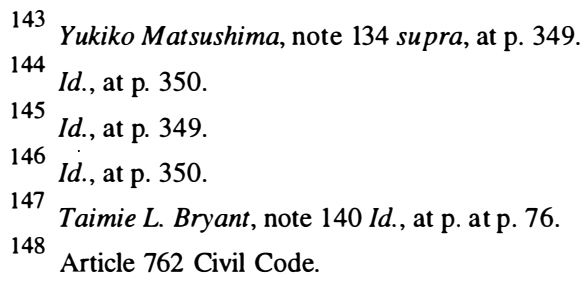


guished scholar of the sociology of law and civil law, professor emeritus at the University of Tokyo and a member of the governmental family law reform committee, has commented in this regard:

Not until we have gained true sexual equality will the realisation of true individual dignity be achieved. As was stated in the written opinion of the Advisory Council to the President of the Headquarters for the Planning and Promoting of Policies Relating to Women, on April 10, 1991:

Half the world is made up of women. Without women's participation in planning we cannot consider the future direction of society in the twenty-first century. Indeed, it is precisely through the decision-making process, whereby women and men take part equally in the planning of government policies and plans in every area, that the development and stability of human society is realized.

A reconsideration [of] the current family law is part of the effort to create the conditions for this purpose. We are on the verge of stepping into a new family law era. ${ }^{149}$

It is to be hoped that family law reform will lead to real gender equality in family law, but it is not a simple task.

\section{Conclusion}

It is often said that Japanese culture is unique, especially in terms of its familial ideology and its hierarchical society. I hope to have demonstrated that cultural attitudes about the role of women spring not so much from inherent cultural beliefs, but are positively promoted by the State in education and family policies. Japan's economic success depends to a large degree on the maintenance of the present employment system and on the flexibility that female part-time and temporary work offers in times of business fluctuations. The State benefits from the economic success of Japanese companies and relies on the division of labour between men and women for its family based welfare system. The current family law disadvantages women who have responded to State promoted cultural pressures and stayed in the home to look after their children and support their husbands further by denying them appropriate property settlements after divorce.

Family law reform on its own will achieve little to address the present subordinate position of women in Japanese society. The Equal Employment Opportunity Act demonstrates that law by itself does little to affect social reality. If the Japanese government wishes to fulfil the constitutional mandate of true gender equality, the following initiatives could prove effective in combination with family law reform: a change of family policies away from 
support for the sex based division of labour between men and women; a reduction of working hours to enable husbands to take an active role in the family; an increase in funding for childcare facilities as well as welfare payments for the elderly; true affirmative action legislation coupled with effective penalties for non-compliance; protection of parttime and temporary workers in terms of minimum wages, benefits, night and overtime work; a removal of gender bias in education policies and practices; and effective enforcement mechanisms for child support and property division after divorce. It is very doubtful, however, that any of these initiatives can be implemented in the short term. Effective education to change the currently prevailing opinions about gender roles and the sex based division of labour would be a vital first step to achieve support for any of these initiatives throughout Japanese society. 


\title{
Symbolical Constitutionalization and Effective De-Constitutionalization: Changes of and in Constitutional Documents and the Continuation of the Distribution of Power
}

\author{
By Marcelo Neves
}

The debate on constitutionalization and de-constitutionalization, even in the countries of the South, has concentrated on the situation formed by the normative constitutions of Northern America and of Western Europe, all of which are governed by the Rule of Law. The arguments of the debate reached Brazil and other peripheral (developing) countries almost totally unfiltered. Thus, there is a need to reconsider the questions with reference to the situation in modern-peripheral countries like Brazil.

The first part of the article focuses on traditional constitutional theory. The second part describes - on the basis of experiences in Brazil as a modern-peripheral country - the notion of effective de-constitutionalization, i.e. the practice of individuals, institutions and private organizations to distort and misuse the text of the constitution both in the political and legal sphere. In the light of this practice, many amendments to the Constitution of Brazil may be characterized as symbolical constitutionalization. In the final part the author describes the positive effects of symbolical constitutionalization on social change and indicates the limits to the practice of symbolical constitutionalization.

The article intends to initiate a new discussion about these constitutional developments in to-day Brazil.

\section{Gender Equality under the Japanese Constitution}

\section{By Annette Marfording}

The Japanese Constitution 1945 introduced the recognition and protection of gender equality. Equal rights for women were subsequently implemented in electoral, educational, employment and family laws. In 1986, the Equal Employment Opportunity Act came into force.

This article explores to what extent the Japanese government has fulfilled the constitutional mandate of gender equality, in particular, whether it has demonstrated a commitment to substantial rather than purely formal gender equality. The focus is on education, employment and family law, examined from a historical, legal, political, economic and cultural perspective. 